Food, Dairy and Home Economic Research

http:/www.journals.zu.edu.eg/journalDisplay.aspx?Journalld=1\&queryType=Master

\title{
EFFECT OF MORINGA LEAVES (Moringa oleifera Lam.) EXTRACT ADDITION ON LUNCHEON MEAT QUALITY
}

\section{Eman S. Abd El-Rahman", G. Abdulla, Gada M. El-Araby, S.E. El-Nemr and Gehan A. El-Shourbagy}

Food Sci. Dept., Fac. Agric., Zagazig Univ., Egypt

Received: 27/08/2019 ; Accepted: 15/09/2019

\begin{abstract}
The effect of addition moringa leaves extract (MLE) on physical, chemical and sensory properties of luncheon was investigated. Luncheon samples were supplemented with $0.5,1.0$ and $1.5 \%$ of MLE. Results showed that supplementation of luncheon with MLE increased its content of protein, fiber and antioxidants. Protein content ranged from $8.49 \%$ in control to $10.90 \%$ in luncheon sample with $1.5 \%$ MLE. Total phenolic content of MLE was ranged from 65 to $67 \mathrm{mg} / 100 \mathrm{~g}$ (as Gallic acid equivalent) while, the scavenging effects of $100 \mu \mathrm{l}$ of MLE were ranged from 79.51 to $88.57 \%$. The thiobarbituric acid number (TBA) values increased for all the investigated luncheon samples gradually during storage period. The highest value for TBA was noticed in L1 (control sample 1) (0.5239) after four weeks of cold storage while, the lowest value was observed with luncheon meat containing $0.01 \%$ butylated hydroxytoluene (BHT) (L2) (0.1251) at zero storage. The total polyphenol contents and antioxidants activity increased in luncheon meat after the addition of moringa leaves extract. All the luncheon meat samples containing moringa leaves extract were generally acceptable.
\end{abstract}

Key words: Moringa leaves, extract, luncheon, antioxidant, sensory evaluation.

\section{INTRODUCTION}

Moringa (Moringa oleifera L.) is a kind of local medicinal Indian herb which has turn out to be familiar in the tropical and subtropical countries. The other expressions used for Moringa are Horseradish tree, Mulangay, Mlonge, Benzolive, Drumstick tree, Sajna, Kelor, Saijihan and Marango. Moringa oleifera is shown in scientific division to become from Kingdom: Plantae, Division: Magnoliphyta, Class: Magnoliopsida, Order: Brassicales, Family: Moringaceae, Genus: Moringa, Species: M. oleifera (Fahey, 2005).

Moringa belonging to the family of Moringaceae is an efficient remedy for malnutrition. Moringa is rich in nutrition owing to the presence of assortment of essential phytochemicals present in its leaves, pods and seeds. In fact, moringa is said to provide 7 times more vitamin $\mathrm{C}$ than oranges, 10 times more

\footnotetext{
*Corresponding author: Tel. : +201094913114

E-mail address: e.s.abderahman@gmail.com
}

vitamin A than carrots, 17 times more calcium than milk, 9 times more protein than yoghurt, 15 times more potassium than bananas and 25 times more iron than spinach (Rockwood et al., 2013).

Ozumba (2011) reported that moringa is an exceptionally nutritious vegetable tree with varieties of potential value. The leaves are eaten as vegetable in many cultures, either fresh or packaged. In Ghana, they are cooked and eaten like spinach or used to make soups, sauces or salads.

Lockett and Calvert (2000), Newton (2007), Mukunzi et al. (2011) and Satya et al. (2012) stated that the leaves, seeds and flowers of Moringa all have great nutritional and curative values. The seeds are eaten like peas or roasted like nuts whilst the flowers are eaten when cooked and taste such as mushrooms.

Ozumba (2011) noticed that in many tropical and subtropical countries, different parts 
of moringa (leaves, fruits, immature pods, and flowers) are integrated into the traditional food of humans. Moringa is one of the nature's gifts to humanity because of its several wealth in vitamins and minerals as well as natural antioxidants.

Moringa is rich in phytosterols such as stigmasterol, sitosterol and kampesterol which are precursors for hormones. These compounds increase the estrogen production, which in turn stimulates the proliferation of the mammary gland ducts to produce milk. It is used to treat malnutrition in children younger than 3 years (Mutiara et al., 2013).

Each part of this plant is a storehouse of important nutrients and antinutrients. The leaves of $M$. oleifera are rich in minerals such as calcium, potassium, zinc, magnesium, iron and copper (Kasolo et al., 2010). Vitamins like vitamin $A$, vitamin $B$ like folic acid, pyridoxine and nicotinic acid, vitamin $\mathrm{C}, \mathrm{D}$ and $\mathrm{E}$ are also present in M. oleifera (Mbikay, 2012). Phytochemicals like tannins, sterols, terpenoids, flavonoids, saponins, anthraquinones, alkaloids and reducing sugar are present along with anticancerous agents such as glucosinolates, isothiocyanates, glycoside compounds and glycerol-1-9-octadecanoate (Berkovich et al., 2013).

Moringa is considered one of the most beneficial trees, in the world, as almost each part of the moringa tree can be used for food, medication and industrial purposes (Khalafalla et al., 2010).

Moringa leaves have been reported to be a rich source of $\beta$-carotene, protein, vitamin $C$, calcium and potassium and act as a good source of natural antioxidants; and thus enhance the shelf-life of fat containing foods due to the presence of diffrent types of antioxidant compounds like ascorbic acid, flavonoids, phenolics and carotinoids (Dillard and German, 2000; Siddhuraju and Becker, 2003).

Luncheon meat is an important industrial meat product, one of the most agreeable food products, widely consumed and used for fast food. It is usually be formed of finely chopped meat and fat with or without some added cereals, cured with salt and nitrite and heat processed (Ranken, 1984). Minced meat undergo oxidative changes and develop rancidity more quickly than intact muscle since grinding exposes more of the muscle surface to air and microbial contamination (Mitsumoto et al., 2005).

Much attention has been concentrated on extracts from herbs and spices which have been utilized traditionally to improve the sensory characteristics and extend the shelf-life of foods (Botsoglou et al., 2003).

Refrigeration storage is usually the most common preservative method of meat and meat products. In order to increase refrigerated storage time, antimicrobial and antioxidant additives are added to foods (Solomakos $\boldsymbol{e t}$ al., 2008). So, the use of natural antioxidants from plants to produce luncheon roll meat of high quality and safety is important.

Thus, the aim of this paper is to study the chemical composition of moringa leaves and examine the effect of adding moringa leaves extract to luncheon roll meat during refrigerate storage on its physical, chemical and sensorial properties.

\section{MATERIALS AND METHODS}

\section{Materials}

Moringa leaves powder (Moringa oleifera lam) was obtained from Agricultural Research Center, Giza, Egypt.

All ingradients used in the preparation of luncheon meats were purchased from local super market at Zagazig District, Sharkia Governorate, Egypt.

\section{Methods}

\section{Preparation of Extracts from Moringa Leaves}

Moringa powder was extracted according to the method of Vongsak et al. (2013). About 50 $\mathrm{g}$ of moringa leaves powder was mixed with $1 \mathrm{~L}$ of $70 \%$ ethanol $(1: 20 \mathrm{~W} / \mathrm{V})$ for $72 \mathrm{hr}$., at room temperature with occasional shaking. The mixture was centrifuged at $3000 \mathrm{X} \mathrm{g}$ for at $20^{\circ} \mathrm{C}$ 10 min then; it was filtered through Whatman No. 1 filter paper. The ethanolic mixture was 
concentrated under vacuum at $45^{\circ} \mathrm{C}$ using a rotary evaporator (Buchi Waterbath B-480 with Buchi Rotavapor R-124, Germany) to obtain the crude extract. The extract was freeze dried (Vacuum freeze dryer model: FDF 0350; Korea). The extract was stored in an air-tight container at $-18^{\circ} \mathrm{C}$ until use.

\section{Luncheon Rolls Meat Preparation}

The luncheon roll meat batter was prepared according to the following formula listed in Table 1. The procedure used in preparation of luncheon samples was carried out according to the protocol described by Zhanc et al. (2004) with some modifications. Processing of the luncheon samples involved blending the minced meat and fat with the other ingredients. Five batches of luncheon were manufactured: sample (L1) prepared as control without any additives; Sample (L2) was prepared by adding 0.01\% BHT.Samples (L3), (L4) and (L5) were prepared by adding $0.5,1.0$ and $1.5 \%$ moringa leaves extract, respectively. Each sample was mixed well to be homogenous and packaged in sealed food bags and fibrous casings (about 500g each) and sealed. Also wrapped in aluminum foil and sealed well. Luncheon rolls were cooked in boiled water for an hour and a half then it let to cool down. The luncheon roll meats were stored in the refrigerator until analysis which was performed at different periods of cold storage.

\section{Chemical Composition}

Moisture, ash, crude protein, crude lipids, crude fiber, and ash of moringa leaves and luncheon samples were determined according to the methods recommended by AOAC (2005), while total carbohydrate content was calculated by difference. All analyses were conducted in central lab for soil, food and feed staff(CLSFF), Faculty of Technology and Development, Zagazig University, Egypt.

\section{Determination of Total Phenolic Content (TPC)}

The concentration of total phenols was measured by spectrophotometer (Jenway-UVVIS Spectrophotometer) based on a colorimetric oxidation/reduction reaction, as described by Skerget et al. (2005) using Folin-Ciocalteu as oxidizing reagent (AOAC, 2005). To $0.5 \mathrm{ml}$ of diluted extract (10 $\mathrm{mg}$ in $10 \mathrm{ml}$ solvent), $2.5 \mathrm{ml}$ of Folin-Ciocalteu reagent (diluted 10 times with distilled water) and $2 \mathrm{ml}$ of $\mathrm{Na}_{2} \mathrm{CO}_{3}(75 \mathrm{~g} / \mathrm{l})$ were added. The sample was incubated at $50^{\circ} \mathrm{C}$ for $5 \mathrm{~min}$ then cooled. For the control sample, $0.5 \mathrm{ml}$ of distilled water was used. The absorbance was measured at $760 \mathrm{~nm}$. Quantification of TPC was based on a Gallic acid standard curve generated by preparing $0,5,10,15,20,30 \mathrm{ml} / 1$. of Gallic acid equivalent (GAE) and calculated using the following linear equation based on the calibration curve:

$\mathrm{y}=0.015 \mathrm{x}+0.0533$

$\mathrm{R}^{2}=0.9966$

Where (y) is the absorbance

$(\mathrm{x})$ is the concentration (mg GAE $\mathrm{g}^{-1}$ extract). $\mathrm{R}^{2}=$ Correlation Coefficient.

\section{Determination of Antioxidants Activity}

Antioxidants activity was determined by DPPH (2.2-diphenyl-1picryl hydrazyle) method, scavenging effect (DPPH method) was adopted to assess antioxidative potential of the moringa extract as follows: The electron donating ability of the obtained extract was measured by bleaching of the purple coloured solution of DPPH according to the method of Hanato et al., (1988). One hundred $\mu l$ of each extracts $(10 \mathrm{mg}$ extract/ $10 \mathrm{ml}$ solvent) was added to $3 \mathrm{ml}$ of 0.1 $\mathrm{mM}$ DPPH dissolved in ethyl acetate and ethanol according to the solvent used for extraction. After 30, 60, 90, and $120 \mathrm{~min}$ incubation periods at room temperature, the absorbance was estimated against a control at $517 \mathrm{~nm}$ (Gulcin, 2012). Percentage of antioxidant activity of free radical DPPH was calculated as follows:

Antioxidant activity (inhibition \%) =

A control - A sample

$$
\text { A control } \times 100
$$

Where:

A control is the absorbance of the control reaction. A sample is the absorbance in the presence of plant extract. Tertbutylhyydroquinone (TBHQ) was used as positive control.

\section{Determination of Thiobarbituric Acid Test (TBA)}

Thiobarbituric acid value was measured according to the method described by Fernandez et al. (2005). About ten grams of 
Table 1. Formula of control luncheon sample

\begin{tabular}{lcc}
\hline Ingredient & $\mathbf{( \% )}$ & Weight $(\mathbf{g})$ \\
\hline Minced lean beef meat & 65 & 325 \\
Back beef fat & 15 & 75 \\
Egg & 5 & 25 \\
Salt & 2.5 & 12.5 \\
Spices & 1 & 5 \\
Garlic powder & 0.5 & 2.5 \\
Onion powder & 2 & 10 \\
Potato starch & 4 & 20 \\
Ice & 5 & 25 \\
Total & 100 & 500 \\
\hline
\end{tabular}

sample was blended with $100 \mathrm{ml}$ distilled water for $2 \mathrm{~min}$. The $\mathrm{pH}$ of the sample was adjusted to 1.5 by adding few drops of $4 \mathrm{~N} \mathrm{HCl}$ and then transferred to a distillation tube. The mixture was distilled and $50 \mathrm{ml}$ distillate was collected. Five $\mathrm{ml}$ of $0.02 \mathrm{M}$ 2- thiobarbituric acid in $90 \%$ acetic acid (TBA reagent) were added to a vial containing $5 \mathrm{ml}$ of the distillate and mixed well. The vials were capped and heated in a boiling water bath for $30 \mathrm{~min}$ to develop the chromogen and cooled to room temperature. The absorbance was measured at $538 \mathrm{~nm}$, against a blank, using JENWAY 6705 UV/VIS spectrophotometer. The TBA values were calculated as $\mathrm{mg}$ malondialdehyde/kg sample according to the following equation:

TBA value $(/ \mathrm{kg})=$ absorbance at $538 \mathrm{~nm} \times 7.8$

\section{Colour Determination}

Colour properties of luncheon were performed using Hunter Lab colour analyzer (Hunter Lab Colour Flex EZ, USA) according to Singh et al. (2008). The $L$ value (lightness index scale) ranges from 0 (black) to 100 (white), while a value indicates the redness $(+a)$ or greenness $(-a)$ and the $b$ value refers to the yellowness $(+b)$ or blue $(-b)$.

\section{Sensory Evaluation}

\section{Sensory evaluation of luncheon meat}

The sensorial criteria (taste, flavour, texture, appearance and colour) of under investigation luncheon samples were evaluated by twenty five untrained panelists. Luncheon samples were cut into $2 \mathrm{~mm}$ thick slices and served in numericallycoded glass petri dishes. Each panelist received five coded samples (one from each tested samples) then independently evaluated the luncheon meat for texture, flavour, colour, appearance and taste using a 5-point hedonic scale $(1=$ extremely poor, $2=$ poor, $3=$ acceptable, $4=$ good, $5=$ excellent), according to the described method of Lavrova and Krilov (1975).

\section{Statistical Analysis}

The results were reported as mean \pm standard deviation (SD) $(\mathrm{n}=3)$ and were statistically investigated using one-way analysis of variance (ANOVA) with Duncan by SPSS for Windows 16.0. A statistical probability ( $p$ value) less than 0.05 indicated a statistically significant difference between groups (Steel and Torrie, 1980).

\section{RESULTS AND DISCUSSION}

\section{Chemical Composition of Luncheon Samples and Moringa Leaves}

The chemical composition of luncheon samples is presented in Table 2. The moisture content of luncheon samples ranged between 52.97 and $57.60 \%$. From the results it was noticed that, moisture content was decreased with the addition of moringa leaves extract. Protein content was increased in luncheon samples fortified with MLE, it was ranged 
Table 2. Chemical composition of the prepared luncheon meat treatments

\begin{tabular}{ccccccc}
\hline Sample & \multicolumn{5}{c}{ (\%) } \\
\cline { 2 - 7 } & Moisture & $\begin{array}{c}\text { Crude } \\
\text { protein }\end{array}$ & $\begin{array}{c}\text { Crude } \\
\text { fat }\end{array}$ & Ash & $\begin{array}{c}\text { Crude } \\
\text { fiber }\end{array}$ & Carbohydrate \\
\hline L 1 & $57.60^{\mathrm{a}} \pm 0.08$ & $8.49^{\mathrm{e}} \pm 0.01$ & $8.04^{\mathrm{e}} \pm 0.05$ & $3.27^{\mathrm{e}} \pm 0.05$ & $3.04^{\mathrm{e}} \pm 0.01$ & $19.56^{\mathrm{c}} \pm 0.02$ \\
L 2 & $57.03^{\mathrm{b}} \pm 0.03$ & $8.45^{\mathrm{e}} \pm 0.02$ & $8.02^{\mathrm{d}} \pm 0.02$ & $3.19^{\mathrm{e}} \pm 0.05$ & $3.06^{\mathrm{e}} \pm 0.04$ & $20.25^{\mathrm{b}} \pm 0.04$ \\
L 3 & $54.12^{\mathrm{c}} \pm 0.04$ & $9.61^{\mathrm{d}} \pm 0.01$ & $8.21^{\mathrm{d}} \pm 0.01$ & $3.92^{\mathrm{d}} \pm 0.05$ & $3.42^{\mathrm{d}} \pm 0.02$ & $20.72^{\mathrm{c}} \pm 0.05$ \\
L 4 & $53.64^{\mathrm{d}} \pm 0.04$ & $10.08^{\mathrm{c}} \pm 0.02$ & $8.75^{\mathrm{c}} \pm 0.01$ & $4.26^{\mathrm{c}} \pm 0.02$ & $3.76^{\mathrm{c}} \pm 5.29$ & $19.51^{\mathrm{c}} \pm 0.03$ \\
L 5 & $52.97^{\mathrm{e}} \pm 0.04$ & $10.90^{\mathrm{b}} \pm 0.01$ & $9.070^{\mathrm{b}} \pm 0.03$ & $4.57^{\mathrm{b}} \pm 0.01$ & $3.91^{\mathrm{b}} \pm 0.01$ & $18.58^{\mathrm{d}} \pm 0.02$ \\
Moringa leaves & $5.90^{\mathrm{e}} \pm 0.01$ & $22.16^{\mathrm{a}} \pm 0.01$ & $10.70^{\mathrm{a}} \pm 0.06$ & $11.77^{\mathrm{a}} \pm 0.01$ & $9.91^{\mathrm{a}} \pm 0.01$ & $39.56^{\mathrm{a}} \pm 0.03$
\end{tabular}

* The results are presented as the mean value \pm SD. Values expressed with different treatments are significantly different at $\mathrm{P}<0.05 \mathrm{~L} 1$ : Control (Luncheon meat free from moringa leaves extract)- L2: Luncheon meat containing $0.01 \%$ BHT- L3: Luncheon meat containing $0.5 \%$ moringa leaves extract- L4: Luncheon meat containing $1 \%$ moringa leaves extract- L5: Luncheon meat containing $1.5 \%$ moringa leaves extract.

between $8.49 \%$ in control sample L1 to $10.90 \%$ in L5 (luncheon with 1.5\% MLE). Table 2 show also that there is a gradual increase in ash and crude fiber contents with the addition of MLE. These results are consistent with the findings of Abdullah (2007).

The chemical composition of moringa leaves is tabulated in Table 2. From the results it could be noticed that the moisture, protein, fat, ash and fiber contents were 5.90, 22.16, 10.70, 11.77 and $9.91 \%$, respectively. These results are in agreement with the findings of Satwase $\boldsymbol{e t}$ al. (2013), Offor et al. (2014) and Mansour (2017).

\section{Total Phenolic Compounds in Moringa Leaves (TPC)}

Phenolic compounds and flavonoids are very important constituents due to antioxidants activity. Moringa leaves regarded as a promising rich source of phenolic compounds. The Polyphenol contents of moringa leaves extract was determined. The total phenolic content was ranged from 65 to $67 \mathrm{mg} / 100 \mathrm{~g}$ (as Gallic acid equivalent). These result are in agreement with those reported by Mansour (2017) who found that total polyphenol content $(65.5 \mathrm{mg} / 100 \mathrm{~g})$ was recorded for the oven dried samples at $70^{\circ} \mathrm{C}$, and Singh and Prasad (2013) who found that the total polyphenol content of moringa leaves ranged from 23.57 to $155.15 \mathrm{mg} / 100 \mathrm{~g}$ depending on the drying temperature, particle size and blanching process. El-Masry et al. (2013) reported that total polyphenol contents were reduced as a result of drying process in comparison with fresh samples.

\section{Antioxidant Activity of Moringa Leaves Extract}

Table 3 show the antioxidants activity of moringa leaves extract. The antioxidants activity determind by DPPH of moringa leaves powder was ranged from 79.51 to $88.57 \%$ (zero time to 120 min.). This result agree with that of the antioxidants activity reported by Mansour (2017) who found that dried moringa leaves powder was $92.46 \%$. Pakade et al. (2013) found that the antioxidants activity of moringa was in the range from 59.8 to $40.4 \%$. In view of the above, Moringa leaves can be considered as a good source of natural antioxidants.

\section{Changes in Thiobarbituric Acid (TBA) of Luncheon Meat During Cold Storage}

The TBA of luncheon meat during cold storage is shown in Fig. 1. From the results, it was found that moringa leaves extract decreased the formation of TBA in luncheon samples during the cold storage period (four weeks). Results indicated also that TBA values of the luncheon samples showed no great differences between all prepared samples at zero time. 
Table 3. Antioxidant activity of Moringa leaves extract

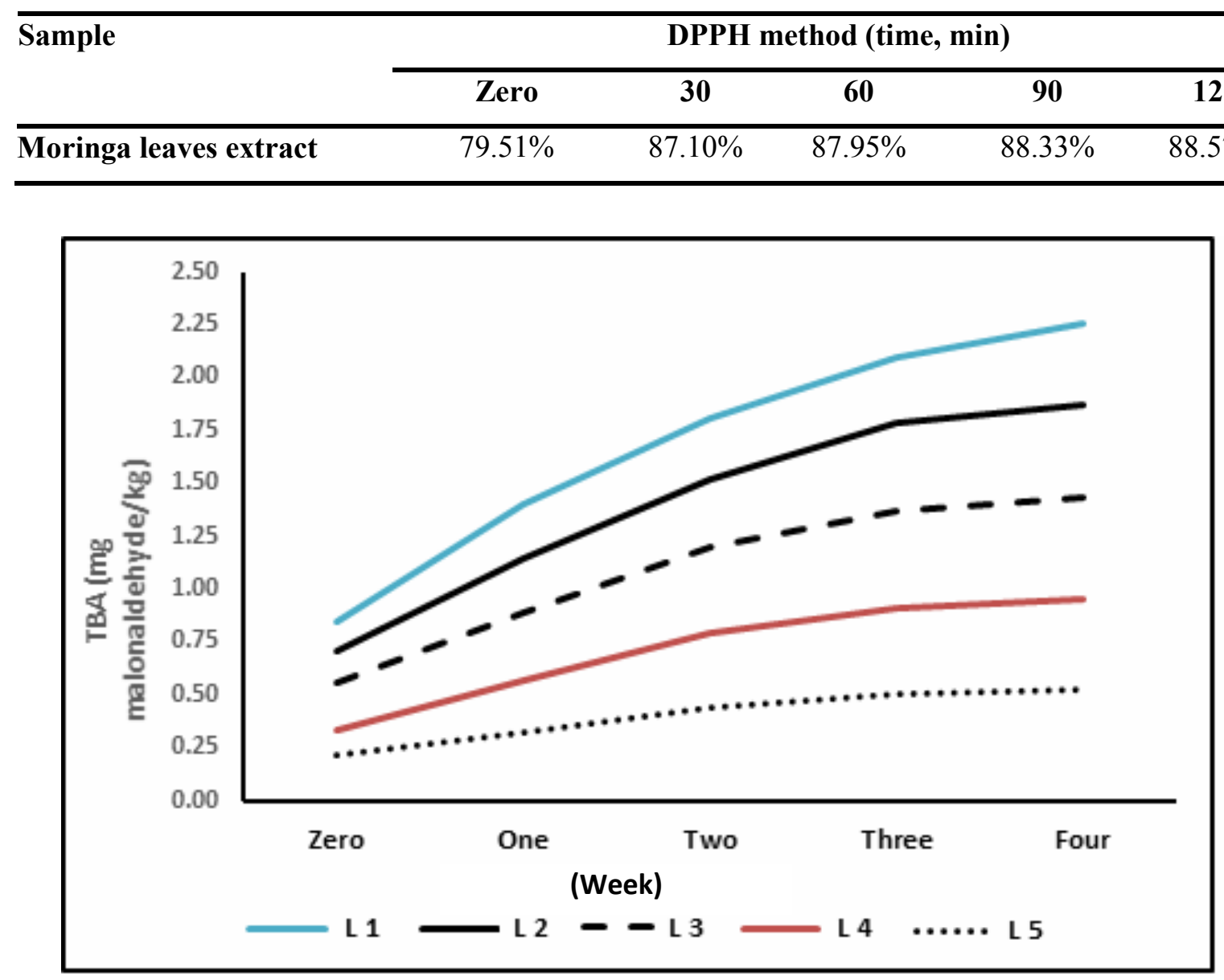

Fig. 1. Changes in TBA (mg malonaldehyde/kg) of luncheon meat treatments during cold storage

These values increased for all the investigated samples gradually during storage period. The highest value for TBA was noticed in control sample (0.5239) after four weeks of cold storage while, the lowest value was observed with L2 (0.1251) at zero storage. The highest value of TBA was determined after four weeks of cold storage with each of the following treatments L1, L2, L3, L4 and L5 (0.524, 0.428, 0.484, 0.437 and 0.382 , respectively). Furthermore, when frozen fat is used, especially at high levels, oxidative rancidity resulting from excessively long storage commonly occurs (Pearson and Tauber, 1984).

\section{Colour Evaluation of Luncheon Meat}

Colour analysis of food product is an important parameter defining consumer's choice and acceptability and controlling the first impression of the food product. The colour values of luncheon samples are presented in Table 4. Lightness $\left(\mathrm{L}^{*}\right)$ was 39.15 in zero time and 38.82 after 15 days (control luncheon meat). Lightness ( $\left.\mathrm{L}^{*}\right)$ was decreased in L4 after 15 days and increased in L2, L3 and L5 (zero time and after 15 days). Redness (a* value) was increased to 15.36 and 17.86 in L4 (zero time and after 15 days) as compared to that observed in control (L1); 13.66 and 14.73 (zero time and after 15 days), and decreased in L2, L3 and L5. Treatments on the other hand, the yellowness (b* value) was no great differences between all prepared samples where ranged from 12.73 to 14.43 but increased to 15.09 in L5 (after 15 days) and 16.31 in L3 (after 15 days). 
Table 4. Colour evaluation of luncheon meat

\begin{tabular}{ccccc}
\hline \multicolumn{2}{c}{ Sample } & $\mathbf{L}^{*}$ & $\mathbf{a}^{*}$ & $\mathbf{b}^{*}$ \\
\hline \multirow{2}{*}{$\mathbf{~ 1}$} & $\mathbf{0}$ time & $39.15^{\mathrm{f}}$ & $13.66^{\mathrm{d}}$ & $13.64^{\mathrm{e}}$ \\
& $\mathbf{1 5}$ days & $38.82^{\mathrm{g}}$ & $14.73^{\mathrm{c}}$ & $12.84^{\mathrm{f}}$ \\
$\mathbf{L} \mathbf{2}$ & $\mathbf{0}$ time & $42.09^{\mathrm{d}}$ & $3.86^{\mathrm{i}}$ & $13.85^{\mathrm{d}}$ \\
& $\mathbf{1 5}$ days & $42.09^{\mathrm{d}}$ & $3.77^{\mathrm{j}}$ & $14.43^{\mathrm{c}}$ \\
$\mathbf{L} \mathbf{3}$ & $\mathbf{0 ~ t i m e}$ & $40.75^{\mathrm{e}}$ & $4.62^{\mathrm{g}}$ & $13.98^{\mathrm{d}}$ \\
& $\mathbf{1 5}$ days & $43.02^{\mathrm{b}}$ & $5.45^{\mathrm{e}}$ & $16.31^{\mathrm{a}}$ \\
$\mathbf{L} \mathbf{4}$ & $\mathbf{0}$ time & $35.29^{\mathrm{i}}$ & $15.36^{\mathrm{b}}$ & $10.79^{\mathrm{g}}$ \\
& $\mathbf{1 5}$ days & $38.42^{\mathrm{h}}$ & $17.86^{\mathrm{a}}$ & $12.73^{\mathrm{f}}$ \\
$\mathbf{L} \mathbf{5}$ & $\mathbf{0 ~ t i m e}$ & $42.66^{\mathrm{c}}$ & $5.22^{\mathrm{f}}$ & $14.42^{\mathrm{c}}$ \\
& $\mathbf{1 5}$ days & $45.57^{\mathrm{a}}$ & $4.32^{\mathrm{h}}$ & $15.09^{\mathrm{b}}$ \\
\hline
\end{tabular}

(L*):- Lightness $\quad\left(a^{*}\right)$ :- Redness $\quad\left(b^{*}\right)$ :- yellowness

\section{Changes in Total Phenolic Compounds and Antioxidant Activity of Luncheon Meat}

The polyphenolic contents of luncheon meat were determined, and the obtained results are presented in Table 5. The total polyphenol contents were $38.82,72.7,75.51,76.89$ and 79.9 $\mathrm{mg} / 100 \mathrm{~g}$ in L1, L2, L3, L4 and L5 treatments, respectively.

Table 5 show the antioxidants activity of luncheon meat during cold storage. The antioxidants activity determined by DPPH of luncheon meat was 20.4 in L1, then increased with the addition of moringa leaves extract, from 53.9 in L2 to 62.8 in L5 treatments.

\section{Sensory Evaluation of Luncheon Meat}

Results of sensory evaluation indicated that all the luncheon meat samples containing moringa leaves extract were generally acceptable for all tested parameters as nonscored below the minimum acceptable rating of three (Table 6). However, these luncheon meats were signficanty differ from content. Results in Table 6 shows the results of L1, L2 and L3 are approximated. The results of sensory tasting showed that the taste was acceptable with good score for all luncheon meat samples. Flavor score was found to be the highest in L1 compared to other studied luncheon samples; while L5 was of worst score. The highest colour score was for L1 and L4, followed by L2, meanwhile the L3 and L5 showed a relative low score. However, all the investigated samples (including the control) realized good colour scores. With regard to texture, L1 was found to be of highest texture score; while L5 was of lowest score. The highest score in appearance was 4.5 in L4 while, the lowest was 3.7 in L5. Abu-Salem et al. (2011) showed that the texture ranged from 3.7 to 4.0 , flavour ranged from 3.7 to 4.2 , colour ranged from 4.1 to 4.4 and taste ranged from 3.8 to 4.1 .

\section{Conclusion}

This investigation shows the potential value of moringa leaves extract (MLE) as a good natural source of nutritive components, total phenolic compounds and antioxidants. Based on its total phenolic compounds and antioxidants, moringa leaves extract could be very suitable as a natural additive or substituted material in the production of many foodstuffs. The information obtained in the present investigation is useful for characterizing moringa leaves extract and for the industrial utilization in luncheon meat preparation. The addition of different concentrations of moringa leaves extract improved the quality criteria of luncheon and increased the values of total phenolic compound and antioxidants activity of luncheon after added moringa leaves extract. 
Table 5. Changes in total phenolic compounds and antioxidant activity of luncheon meat as affected by treatments preparteion

\begin{tabular}{lcc}
\hline & Polyphenol contents $\mathbf{( m g / 1 0 0 g )}$ & Antioxidant activity (DPPH) \\
\hline L 1 & $38.82 \pm 0.055$ & $20.4 \pm 0.02$ \\
L 2 & $72.70 \pm 0.042$ & $53.9 \pm 0.013$ \\
L 3 & $75.51 \pm 0.045$ & $55.9 \pm 0.068$ \\
L 4 & $76.89 \pm 0.071$ & $59.1 \pm 0.014$ \\
L 5 & $79.90 \pm 0.063$ & $62.8 \pm 0.07$ \\
\hline
\end{tabular}

Table 6. Sensory evaluation of luncheon meat

\begin{tabular}{cccccc}
\hline Luncheon meat sample & \multicolumn{5}{c}{ Sensory evaluation } \\
\cline { 2 - 6 } & Colour & Appearance & Flavour & Texture & Taste \\
\hline L 1 & $4.3^{\mathrm{a}}$ & $4.1^{\mathrm{ab}}$ & $4.5^{\mathrm{a}}$ & $4.6^{\mathrm{a}}$ & $4.7^{\mathrm{a}}$ \\
L 2 & $4.1^{\mathrm{ab}}$ & $4.1^{\mathrm{ab}}$ & $4.1^{\mathrm{abc}}$ & $4.3^{\mathrm{ab}}$ & $4.3^{\mathrm{ab}}$ \\
L 3 & $3.8^{\mathrm{ab}}$ & $3.9^{\mathrm{b}}$ & $4.0^{\mathrm{bc}}$ & $4.2^{\mathrm{ab}}$ & $4.1^{\mathrm{b}}$ \\
L 4 & $4.3^{\mathrm{a}}$ & $4.5^{\mathrm{a}}$ & $4.4^{\mathrm{ab}}$ & $4.3^{\mathrm{ab}}$ & $4.3^{\mathrm{ab}}$ \\
L 5 & $3.7^{\mathrm{b}}$ & $3.7^{\mathrm{b}}$ & $3.7^{\mathrm{c}}$ & $4.0^{\mathrm{b}}$ & $3.5^{\mathrm{c}}$ \\
\hline
\end{tabular}

\section{REFERENCES}

Abdullah, B.M. (2007). Properties of five canned luncheon meat formulations as affected by quality of raw materials. Int. J. Food Sci. and Technol., 42, 30-35.

Abu Salem, F.M. E.A. Bou Arab, H.M. Ibrahim and A.A. Abou Arab (2011). Effect of adding green tea extract, thyme oil and/or their combination to luncheion roll meat during refrigerate storage. J. Ame. Sci., 7 (7): 538548.

AOAC (2005). Offical Methods of Analysis, Association of Official Analytical Chemists. Food Compositition, additives natural contaminants. Adrich RC (Ed.) (2) $15^{\text {th }} \mathrm{Ed}$. Ass. Official Anal. Chem. Inc. USA.

Berkovich, L., G. Earon, I. Ron, A. Rimmon, A. Vexler and S. Lev-Ari (2013). Moringa oleifera aqueous leaf extract down-regulates nuclear factor-kappaB and increases cytotoxic effect of chemotherapy in pancreatic cancer cells, BMC Complement. Altern. Med., 13: 212-219.

Botsoglou, N.A., S.M. Grigoropoulou, E. Botsoglou, A. Govaris and G. Papageorgiou (2003). The effects of dietary oregano essential oil and atocopheryl acetate on lipid oxidation in raw and cooked turkey during refrigerated storage. Meat Sci., 65: 11931200.

Dillard, C.J. and J.B. German (2000). Phytochemicals: Nutraceuticals and human health: A review. J. Sci. Food Agric., (80): 1744-1756.

El-Masry, F.H.M., M.E.M. Mossa and S.M. Youssef (2013). Moringa oleifera plant. Value and utilization in food processing. Egypt. J. Agric. Res., 91 (4): 1597-1609.

Fahey, J.W. (2005). Moringa oleifera: A review of the medical evidence for its nutritional, therapeutic, and prophylactic properties. Part 1. Trees Life J., 1: 1-15. 
Fernandez, L.J., N. Zhi, C.L. Aleson, J.A. PerezAlvarez and V. Kuri (2005). Antioxidant and antibacterial activities of natural extracts: Application in beef meatballs. Meat Sci., 69: 371-380.

Gulcin, I. (2012). Antioxidant activity of food constituents: An overview. Arch Toxicol., 86: 345-391.

Hanato, T., H. Kagawa, T. Yasuhara and T. Okuda (1988). Two new flavonoids and other constituents in licorice root: their relative astringency and radical scavenging effects. Chem. Pharm. Bull., 36: 2090-2097.

Kasolo, J.N., G.S. Bimenya, L. Ojok, J. Ochieng and J.W. Ogwal-okeng (2010). Phytochemicals and uses of Moringa oleifera leaves in Ugandan rural communities, J. Med. Plants Res., 4: 753-757.

Khalafalla, M.M., E. Abdellatef, H.M. Dafalla, A.A. Nassrallah, K.M. Aboul-Enein, F.D.A. Lightfoot, E. El-Deeb and H.A. El-Shemy (2010). Active principle from Moringa oleifera Lam leaves effective against two leukemias and a hepatocarcinoma. Afr. J. Biotechnol., 9 (49): 8467-8471.

Lavrova, L.P. and V.X. Krilova (1975). Luncheon meat technology, in Russian, Moscow: Food' Industry, 325-326.

Lockett, C.T. and C.C. Calvert (2000). Energy and micronutrient composition of dietary and medicinal wild plants consumed during drought. Study of rural Fulani, Northeastern Nigeria. Int. J. Food Sci. and Nutr., 51(3): 195-208.

Mansour, S. (2017). Chemical and technological studies on moringa leaves. M.Sc. Thesis, Food Sci. Dep., Fac. Agric., Zagazig Univ., Egypt.

Mbikay, M. (2012). Therapeutic potential of Moringa oleifera leaves in chronic hyperglycemia and dyslipidemia: A review, Front. Pharmacol., 3: 1-12.

Mitsumoto, M., M.N. O'Grady, J.P. Kerry and D.J. Buckley (2005). Addition of tea catechins and vitamin $\mathrm{C}$ on sensory evaluation, color and lipid stability during chilled storage in cooked or raw beef and chicken patties. Meat Sci., 69: 773-779.

Mukunzi, D.J., Z. Nsor-Atindana, X.A. Gahungu, E. Karangwa and G. Mukamurezi (2011). Comparison of volatile profile of Moringa oleifera leaves from Rwanda and China using HS-SPME. Pak. J. Nut., 10: 602-608.

Mutiara, T., E.S. Titi and W. Estiasih (2013). Effect lactagogue moringa leaves (Moringa oleifera Lam) powder in rats, J. Basic Appl. Sci. Res., 3 : 430-434.

Newton, K.A. (2007). Effect of spacing and harvest frequency on the growth, leaf quality and yield of Moringa oleifera as a leafy vegetable. M.Sc. Thesis, Fac. Agric. and Natural Res., Knust, 4 - 6.

Offor, I.F., R.C. Ehiri and C.N. Njoku (2014). Proximate nutritional analysis and heavy metal composition of dried Moringa oleifera leaves from Oshiri onicha LGA, Ebonyi State, Nigeria. ISSN. (8): 2319-2399.

Ozumba, N.A. (2011). Moringa oleifera: Nigeria's evergreen gold. Pax Herbal Magazine, 6: 7-9.

Pakade, V.E., E. Cukrowska and L. Chimuka (2013). Comparison of antioxidant activity of Moringa oleifera and selected vegetables in South Africa. South Afr. J. Sci., 109 (314): 1154-1158.

Pearson, A.M. and F.W. Tauber (1984). Processed Meats, $2^{\text {nd }}$ Ed. Westport: AVI Publishing Company, Inc.

Ranken, M.D. (1984). Meat and Meat Products. In: Food Industries Manual, $21^{\text {st }}$ Ed. Chapter, Leonard Hill, USA, 1: 18.

Rockwood, J.L., B.G. Anderson and D.A. Casamatta (2013). Potential uses of Moringa oleifera and an examination of antibiotic efficacy conferred by $M$. oleifera seed and leaf extracts using crude extraction techniques available to under-served indigenous populations, Int. J. Phytothearpy Res., 3 61-71.

Satwase, A.N., G.R. Pandhre, P.G. Sirsat and Y.R. Wade (2013). Studies on drying characteristic and nutritional composition of drumstick leaves by using sun, shadow, 
cabinet and oven drying methods. Open Access Sci. Rep., 2 (1): 1-4.

Satya, P.M., P. Singh and S. Singh (2012). Processing of Moringa oleifera leaves for human consumption. Bull. Env. Pharmacol. Life Sci., 2 (1): 28- 31.

Siddhuraju, P. and K. Becker (2003). Antioxidant properties of various solvent extracts of total phenolic constituents from three different agro climatic origins of drumstick tree (Moringa oleifera Lam.) leaves. J Agric Food Chem., 51 (8): 2144-2155.

Singh, S., C.S. Riar and D.C. Saxena (2008). Effect of incorporating sweet potato flour to wheat flour on the quality characteristics of cookies. Afr. J. Food Sci., 2: 65-72.

Singh, Y. and K. Prasad (2013). Moringa oleifera leaf as functional food powder: characterization and uses. Int. J. Agric. and Food Sci. Technol., 4 (4): 317-324.

Skerget, M., P. Kotnik, M. Hadolin, A. Hras, M. Simonic and Z. Knez (2005). Phenols, proanthocyanidins, flavones and flavonols in some plant materials and their antioxidant activities. Food Chem., 89: 191- 198.

Solomakos, N., A. Govaris, P. Koidis and N. Botsoglous (2008). The antimicrobial effect of thyme essential oil, nisin, and their combination against Listria monocytogenes in minced beef during refrigerated storage. Food Microbiol., 25L 120-127.

Steel, R.G. and J.H. Torrie (1980). Principles and procedures of statistics. London: McGraw Hill.

Vongsak, B., S. Pongtip, M. Supachoke, T. Suchitra, W. Yuvadee and G. Wandee (2013). Maximizing total phenolics, total flavonoids contents and antioxidant activity of Moringa oleifera leaf extract by the appropriate extraction method. Indust. Crops and Prod., 44 : 566-571.

Zhanc, L., J.G. Lyng and N.P. Brunto (2004). Effect of radio frequency cooking on the texture, colour and sensory properties of a large diameter comminuted meat product. Meat Sci., 68: 257- 268.

\footnotetext{
تأثيـــر إضــافة مستخلص أوراق المورينجا على جـودة لانشـــون اللحم

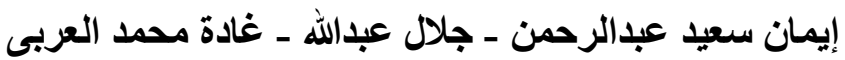

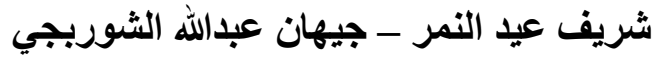

قسم علوم الأغذية ـ كلية الزراعة - جامعة الزقازيق - مصر

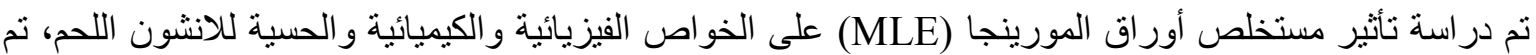

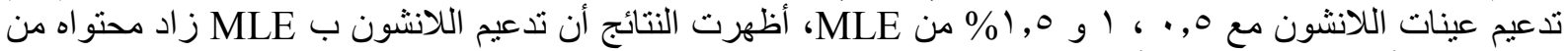

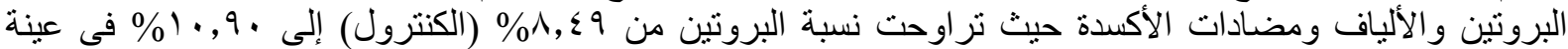

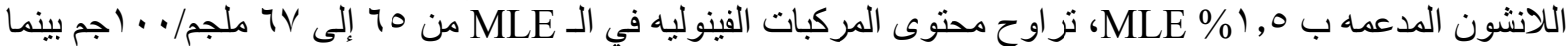

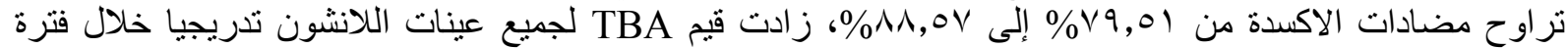

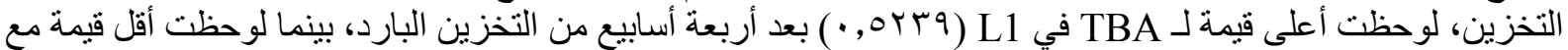

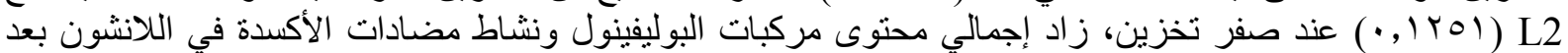

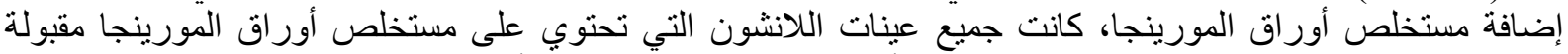

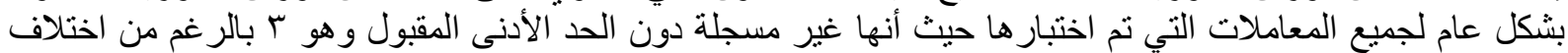

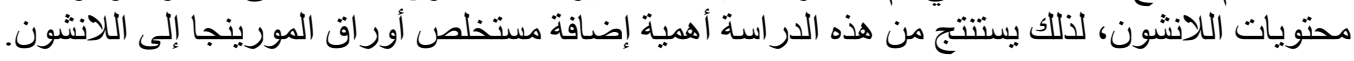

